\title{
NLRP3 wt Allele
}

National Cancer Institute

\section{Source}

National Cancer Institute. NLRP3 wt Allele. NCI Thesaurus. Code C77203.

Human NLRP3 wild-type allele is located in the vicinity of $1 \mathrm{q} 44$ and is approximately $33 \mathrm{~kb}$ in length. This allele, which encodes NACHT, LRR and PYD domains-containing protein 3, is involved in the regulation of both apoptosis and inflammation. Mutation of the gene is associated with familial cold autoinflammatory syndrome, Muckle-Wells syndrome, and chronic infantile neurological cutaneous and articular syndrome. 